\title{
Claudia Schumann Graphic Contaminations: Cosmopolitics of the 'I' in American Born Chinese and Persepolis
}

\begin{abstract}
The article explores the demands that the critical and conflictual dimension of globalization poses for a cosmopolitan education. Such an emphasis seems necessary in times where the populations who undertake inter-and intra-national border crossings are increasingly those who are forced to: those trying to escape unbearable poverty, atrocious wars, the disenfranchised and victims of racist, sexist or religious persecution. Reflecting on the experiences articulated in the two graphic novels, Persepolis and American Born Chinese, the dimension of the globalizing world and its impact and demands on its future world citizens which comes to the fore is one that highlights the necessity for learning how to take a critical and political stance rather than the search for how education can facilitate a smooth adaptation to a new mobile order. Stanley Cavell's examination of the relationship between autobiography, philosophy, and the founding of a self-reliant voice will be reconsidered in light of its contribution to re-thinking the meaning of a cosmopolitan education between critical self-appropriation and developing a transformative political vision of a new societal order.
\end{abstract}

\section{Keywords}

Cosmopolitanism, education, graphic novels, American Born Chinese, Persepolis, Stanley Cavell

\section{Introduction}

One of the most pervasive educational debates in recent decades, from mainstream media to educational policy, research and philosophy, has been shaped by a concern with an apparently radical shift in the conception of public education from a primarily national to a global outlook. Often, what authors mean by the "globalizing world" to which contemporary educational institutions are supposed to adjust comes in highly diverse colours and shapes. It ranges from the emergence of new powerful supranational actors on the educational scene such as IMF, World Bank or the OECD, to globalizing economic structures, neoliberal policies, global cultural changes, to more flexible, mobile and diverse populations as well as to the increase of world-wide communication due to the fast spreading of new media and technologies. The revival of the old ideal of the cosmopolitan and an education for world citizenship can in this context be understood as an attempt to articulate an adequate response to the (perceived) demands that these new social, political,

Claudia Schumann, Stockholms University, Sweden

E-mail: claudia.schumann@edu.su.se

Studier i Predagogisk Filosofi | www.ojs.statsbiblioteket.dk/index.php/spf | ISSN nr. 22449140

Årgang 4 | Nr.2 | 2015 | side 38-53 
economic and cultural developments make on future citizens and hence on educational institutions, actors and practices in the $21^{\text {st }}$ century.

Cosmopolitanism is often felt "to resolve some of the more troublesome antitheses that currently plague cultural interpretation at a global scale - local/global, tradition/ modernity, ordinary culture/high culture."1 Comics are interestingly placed at similar junctions. The comics medium as such has qualities which might justify considering it as almost uniquely apt to articulate and portray cosmopolitan conditions. When Michael A. Chaney emphasizes "the uniquely supple procedures the comics form makes possible for the representation of multiple yet simultaneous timescapes and competing yet coincident ways of knowing, seeing, and being," ${ }^{2}$ he names key features which make it possible to broach central issues pertaining to a cosmopolitan attitude. The joyful as well as the conflictual negotiations, intersections and tensions involved in the simultaneous presence of a multiplicity of cultural, social and political affiliations and commitments can co-exist on the comics page in their temporal variability and their diverse modes of expression.

I will take the emphasis on the critical and conflictual dimension of cosmopolitanism as my starting point in the following analysis. Without underestimating the pleasures of and the desire for transgression, such an emphasis seems necessary in times where the populations who undertake these inter- and intra-national border crossings are increasingly those who are forced to: those trying to escape unbearable poverty, atrocious wars, the disenfranchised and victims of racist, sexist or religious persecution. Reflecting on the experiences articulated in the two graphic novels, Persepolis and American Born Chinese, the dimension of the globalizing world and its impact and demands on its future world citizens which comes to the fore is one that highlights the necessity for learning how to take a critical and political stance rather than the search for how education can facilitate a smooth adaptation to a new mobile order. Stanley Cavell's examination of the relationship between autobiography, philosophy, and the founding of a self-reliant voice will be reconsidered in light of its contribution to re-thinking the meaning of a cosmopolitan education between critical self-appropriation and developing a transformative political vision of a new societal order.

\section{The Promise of Cosmopolitanism and Challenges to the Celebration of Contamination}

The first explicit use of the notion of cosmopolitanism is commonly traced back to an alleged encounter between Diogenes and Alexander the Great, in which Diogenes is said to have replied "I am a citizen of the world" when Alexander asked him where he came

Bruce Robbins, “Cosmopolitanism: New and Newer," boundary 2.34-3 (2007): 49.

2 Michael A. Chaney, ed., Graphic Subjects: Critical Essays on Autobiography and Graphic Novels (Madison: University of Wisconsin Press, 2011), 5. 
from. ${ }^{3}$ Instead of revealing his native polis, which was taken to be a chief formative factor of one's identity at the time, Diogenes announced himself as a kosmopolitês, a citizen of the world. Ever since, the notion has been rearticulated and re-appropriated throughout time in manifold ways. Since the early 1990s, a variety of "new cosmopolitanisms" have emerged, and the notion has since regained so much momentum that Seyla Benhabib called cosmopolitanism "one of the keywords of our times." ${ }^{14}$ The question I want to raise is in which sense we are to read the rejection of local affiliation and the claim to world citizenship. Cosmopolitanism in its classic form, as defended today by a variety of authors, ${ }^{5}$ frequently appeals to universal principles of justice or universal ideas of humanity. Articulated as a clearly normative project, it urges us to take our primary obligation to be towards humanity as such, rather than engage in any forms of classism, sexism, racism, nationalism, or regionalism. Martha Nussbaum, for example, prominently took a distinctive stance against communitarianism in her defense of a Stoic-Kantian cosmopolitanism, for "we have great power over racism, sexism and other divisive passions that militate against cosmopolitan humanism, if we will only devote enough attention to the cognitive moral development of the young." The appeal to reason in Nussbaum's case, as well as the commitment to certain democratic meta-principles like autonomy in other cases, has led to the habitual dismissal of these forms of cosmopolitanism for being just further forms of universalism. Many critics felt that nobody can reasonably expect our care for strangers to exceed our care for our closest family and friends, and that the appeal to certain typically Western ideals of liberalism seemed to be put to work again here in yet another version of western imperialism?

The "new cosmopolitanisms"8 in contrast try to take our various particular attachments into more serious account so that the universal humanism becomes inflected by socio-historical particularisms. However, in distinction from communitarian, particularist, or more strictly culturalist approaches, and in reaction to "certain excesses of identity politics" these cosmopolitanisms recuperate from the classical cosmopolitanism outlined above fleeting fragments of its normative dimension, but at the same time they promise

3 Diogenes Laertius, Book Vl: 63 quoted in ed. Pauline Kleingeld, and Eric Brown, “Cosmopolitanism," in The Stanford Encyclopedia of Philosophy, Fall 2014 Edition.

4 Seyla Benhabib, Another Cosmopolitanism (Oxford: Oxford University Press, 2006), 17, doi: 10.1093/acprof: oso/9780195183221.001.0001.

5 E.g. Martha C. Nussbaum and Joshua Cohen, For Love of Country: Debating the Limits of Patriotism (Boston: Beacon Press, 1996); Martha C. Nussbaum, "Kant and Stoic Cosmopolitanism," Journal of Political Philosophy 5 (2002), doi: 10.1111/1467-9760.00021; David Held, Democracy and the Global Order: From the Modern State to Cosmopolitan Governance (Stanford: Stanford University Press, 1995); Daniele Archibugi, Debating Cosmopolitics (London: Verso, 2003).

6 Nussbaum, "Kant and Stoic Cosmopolitanism," 23.

7 Cf. Robbins, "Cosmopolitanism: New and Newer," 53.

8 Cf. e.g. Amanda Anderson, "Cosmopolitanism, Universalism, and the Divided Legacies of Modernity," in ed. Pheng Cheah et al., Cosmopolitics: Thinking and Feeling Beyond the Nation, (Minneapolis: University of Minnesota Press, 1998); Robbins, "Cosmopolitanism: New and Newer."

9 Anderson, “Cosmopolitanism, Universalism," 265. 
that particular affiliations need not be incompatible with a cosmopolitan orientation that, on the contrary, they might be necessary pre-requisites. The hope which Anderson connects with the new cosmopolitanisms lies in their potential to develop "a more complex conception of detachment, which is often too reductively opposed to a valorized conception of situatedness or, alternatively, too easily celebrated as negative freedom."10 Kwame Anthony Appiah's "rooted cosmopolitanism"11 presents a prominent example for this type of theoretical hybrid between universalism and particularism which "tempers a respect for difference with a respect for actual human beings." ${ }^{\prime 2}$ Similarly, Seyla Benhabib in her argument for Another Cosmopolitanism undertakes to take into account "the significance of membership within bounded communities"13 while arguing that our moral and political obligations and commitments extend also "to those who do not reside within nationally recognized boundaries." ${ }^{14}$ In both Benhabib's and Appiah's view, while the particularism put forth in certain types of multiculturalism or identity politics overemphasizes the respect for otherness to the extent that it might be read to turn into sheer indifference towards the other, universalist endeavors have frequently neglected our particularist boundedness and the reality of present-day pluralism. Whereas Benhabib tries to resolve this tension through the mediation between the moral and the political in terms of a "dialogic universalism,"15 Appiah chooses a more pragmatic approach in focusing on the multifarious possibilities of connecting with concrete others in a pragmatic realm and urges to let go of the fixation on trying to reach agreement on the deep level of values necessarily shared amongst all human beings.

Following Salman Rushdie, Appiah propounds the "ideal of contamination"16 which, in opposition to purist ideals of culture, "celebrates hybridity, impurity, intermingling, the transformation that comes of new and unexpected combinations of human beings, cultures, ideas, politics, movies, songs." ${ }^{17}$ While Appiah admits that "there can be an easy and spurious utopianism of 'mixture,' as there is of 'purity,"'18 he nevertheless considers the cosmopolitan "praise of contamination" to be on the side of "the larger human truth."19 Even though Appiah works with examples from a very different background and despite his insistence on the compatibility of cosmopolitanism with particular bounds, his pragmatic, easily accessible cosmopolitanism bears significant resemblance to Jeremy Waldron's "lifestyle cosmopolitanism," and it invites similar criticisms. Waldron's cosmopolitan, "a

10 Anderson, “Cosmopolitanism, Universalism," 265.

11 Kwame Anthony Appiah, The Ethics of Identity (Princeton, NJ: Princeton University Press, 2005), 213ff.; Cf. also Kwame Anthony Appiah, Cosmopolitanism: Ethics in a World of Strangers (New York: W.W.Norton, 2006).

12 Appiah, Cosmopolitanism, 113.

13 Benhabib, Another Cosmopolitanism, 2.

14 Benhabib, Another Cosmopolitanism, 14.

15 Benhabib, Another Cosmopolitanism, 20.

16 Appiah, Cosmopolitanism, 112.

17 Appiah, Cosmopolitanism, 112.

18 Appiah, Cosmopolitanism, 113.

19 Appiah, Cosmopolitanism, 113. 
creature of modernity, conscious, even proud, of living in a mixed-up world and having a mixed-up self,"20 was described chiefly by examples and features that applied exclusively to a certain privileged class. As Kymlicka rightfully pointed out, cosmopolitanism thus understood seems to boil down to the enjoyment of "the opportunities provided by the diverse societal culture which characterizes the Anglophone society of the United States." ${ }^{21}$ In this way, Waldron's cosmopolitan is not rootless, but uncomfortably rooted in an elitist culture accessible to only few, and it is this which Derrida warns us of when he writes that "no one is more cosmopolitan than the one, than this 'we,' who is speaking to you."22

Appiah's cosmopolitan is meant to be rooted in various forms of ordinary culture. But since the whole point of much of Appiah's argument is that there does not have to be a conflict between our particular affiliations and a simultaneous cosmopolitan orientation, he equally comes to describe cosmopolitanism in terms of the enjoyment of mixing, thus disregarding those cases of conflict where the oxymoron of a "rooted cosmopolitanism" would show itself in its paradoxical structure, and reveal the uncomfortable normative demands that a cosmopolitan orientation might make on us in opposition to our particularist inclinations. Cosmopolitanism in Appiah then becomes much more a descriptor of already existing ways of life under conditions of ever increasing global interconnectedness, rather than a challenge that poses itself again and again in concrete - and equally quotidian - situations of conflict. As Bruce Robbins cautions, "celebrations of cosmopolitan diversity have largely been uninterrupted by the issues of economic equality or geo-political justice." ${ }^{23}$ Against such a "depoliticization"24 I would like to follow Robbins and others in emphasizing the critical core of cosmopolitanism.

Cosmopolitanism should indeed offer an alternative between the two pathological tendencies "to reify local identities or construct universal ones." ${ }^{25}$ Therefore, firstly, I think that the term "cosmopolitan" should be reserved for Diogenes rather than for Alexander the Great, who is more adequately described as emperor. This implies that those forms of moral, political or economic cosmopolitanism which become indistinguishable from a mere factual description of the (positive or negative) consequences of globalization are not of interest to me in the present context. Rather, the kind of cosmopolitics in question is concerned with "cosmopolitan resistances to globalization." ${ }^{26}$ Secondly, I believe that Diogenes did not wish to affirm another substantive, cosmopolitan identity, but that his declaration "I am a citizen of the world" should be read as resisting an acknowledgment of conventional identifications with a critical intent. As I have argued in earlier work, the

20 Jeremy Waldron, “What is Cosmopolitan?," Journal of Political Philosophy 8.2 (2000): 228, 10.1111/1467-9760.00100.

21 Will Kymlicka, Multicultural Citizenship (Oxford: Clarendon Press, 1995), 85.

22 Jacques Derrida, The Other Heading (Bloomington: Indiana University Press), 48.

23 Robbins, "Cosmopolitanism: New and Newer," 51.

24 Robbins, "Cosmopolitanism: New and Newer," 55.

25 Paul Rabinow, "Representations are Social Facts: Modernity and Post-Modernity in Anthropology," in ed. James Clifford et al., Writing Culture, (Berkeley: University of California Press, 1986), 258.

26 Gerard Delanty, "The Cosmopolitan Imagination: Critical Cosmopolitanism and Social Theory," The British Journal of Sociology 57.1 (2006): 31, doi: 10.1111/j.1468-4446.2006.00092.x. 
"critical cosmopolitanism" suggested by Gerard Delanty provides a useful corrective in this regard and the primary concern of cosmopolitan education should be with "resisting being bound by reified entities, and with finding, founding and finding back to non-reifying ways of boundedness." ${ }^{27}$ Gerard Delanty similarly claims that cosmopolitanism "does not arise merely in situations of cultural diversity or taking the perspective of the other," ${ }^{28}$ and that it "is not an identity as such that can be contrasted with national identity or other kinds of identity." 29 I share Delanty's conviction that the "key aspect of cosmopolitanism" is "the transformative vision of an alternative society." ${ }^{30}$

\section{Visualizing the Cosmopolitan Condition: Graphic Novels as a Cosmopolitan Medium?}

In the tradition of Art Spiegelman's Maus both Marjane Satrapi's Persepolis and Gene Luen Yang's American Born Chinese reference the authors' real lived experiences. Yet, they complicate traditional notions of autobiographical authority not just in their joyful "commingling [...] of verbal and visual modes of expression", ${ }^{31}$ but also by placing at the center of the narrative characters who are trying to first establish a voice that could rightfully count as speaking with such authority while "situated at the crossing of boundaries." ${ }^{2}$ Persepolis ${ }^{33}$ was originally published in France in four volumes between 2000 and 2003, but the references in the following will refer to the later two-volume English translation. In the graphic novel Satrapi explores her early childhood and teenage years in Iran, the time of her exile in Austria, where she slowly grows into an adult, her temporary return to Iran, and her eventual final departure for France. In the course of the story we become witness to the Islamic revolution and the ensuing conservative backlash and see young Marji get into trouble with rigid fundamentalism in Iran. Afraid of the consequences, her parents decide to send her to Austria, where she again speaks her mind in the Christian convent she lives in during her first arrival, subsequently being evicted. We see her befriend a group of anarchist punks in the French-speaking boarding school she attends, and even in this group of outsiders Marji becomes the one who questions their norms, conformism and elitism. After a dramatic end of a love affair, she turns back to Iran to the safety of her family, fully aware of the compromises this will require. After a period of adaptation, the political pressure and the social strictures finally become unbearable. The book ends at the airport with her leaving Iran for good this time, knowing she will never see her grandmother again: "freedom had a price".

27 Claudia Schumann, "Boundedness beyond reification: cosmopolitan teacher education as critique," Ethics and Global Politics 5.4 (2012): 230.

28 Delanty, "The Cosmopolitan Imagination," 40.

29 Delanty, "The Cosmopolitan Imagination," 40.

30 Delanty, "The Cosmopolitan Imagination," 40.

31 Chaney, Graphic Subjects, 5.

32 Julia Kristeva, Nations without Nationalism (New York: Columbia University Press, 1993), 16.

33 Marjane Satrapi, Persepolis (London: Vintage, 2008). 
Gene Luen Yang's American Born Chinese ${ }^{34}$ deals with comparatively less violent topics and is directed at a younger audience, but the main character, loosely based on the author's own childhood experiences in an American high school, is confronted with situations which similarly require him to struggle for founding his own voice. Being a less confrontational and courageous person than Marji, the main character nevertheless equally has to find his path through rigidly erected national and cultural boundaries as well as he has to ethically position himself. The story combines three different tales which only towards the end are revealed to be related to each other. One story arc follows the monkey king's rebellion against the gods based on the 16th's century Chinese novel Journey to the West. Despite having superpowers and being a king, the monkey king is not welcome to join the party of the deities because he has no shoes and he smells of monkey. Another story arc follows Jin Wang, a second-generation Chinese immigrant who struggles to blend in into a mostly white American high school, and is insecure whether to befriend a newly arrived Asian immigrant classmate or not. The third storyline, drawn in the style of a sit-com, is about a white American boy named Danny who is disturbed by the occasional visits of his Chinese cousin Chin-Kee. In proper sitcom manner, Chin-Kee embodies all negative racial stereotypes and becomes a constant embarrassment to Danny, causing him not only physical disgust, but also threatening his social status at school. The different characters of the three story arcs are all haunted by the threats and external ascriptions of a racist society, but they are also haunted by their cultural roots with which they have to come to terms in order to overcome the terror of the repressed, but inescapable ghosts.

When turning to Persepolis and American Born Chinese, what might first strike one to consider them as visualizations of a cosmopolitan condition might be the playful ease and pleasure with which the authors draw from and blend most diverse traditions in creating their own visual style. In American Born Chinese Gene Luen Yang not only interweaves three different story lines, but his appropriation of the form of the bildungsroman, the sit-com, and the legend to the comics medium leads to a visual "amalgam of Eastern and Western stories and drawing techniques"; while the drawing style throughout employs a bright and full variety of colors, "the drawing style of Yang's central story line - Disneytype realistic characters - differs from his representation of Chin-Kee, which mimics early nineteenth-century cartoons." 35 Persepolis similarly disrupts visual purisms. While strongly influenced by Persian miniature painting and its typical flatness, the visual style of Satrapi's work at the same time rejects the "color-rich classic tradition of Persian art" employing the "minimalist play of black and white" typical of expressionistic "avant-garde, black-and-white-cinema," ${ }^{37}$ or when she lets herself get inspired by the simplicity and nai-

34 Gene Luen Yang, American Born Chinese (New York: Square Fish, 2006).

35 Roció G. Davis, "American Born Chinese. Challenging the Stereotype," in ed. Michael A. Chaney, Graphic Subjects: Critical Essays on Autobiography and Graphic Novels, (Madison, Wl: University of Wisconsin Press, 2011), 281.

36 Hillary Chute, "The Texture of Retracing in Marjane Satrapi's Persepolis," Women's Studies Quarterly 36.1-2 (2008): 11.

37 Chute, "The Texture," 11. 
vety of the abstract woodcut prints by Swiss born French artist Félix Vallotton. ${ }^{38}$ In both works, Persepolis and American Born Chinese, one of the most transparent examples for their cosmopolitan openness and embrace of contamination can be found in their handling of religious motifs. Satrapi and Yang align and assimilate various religious traditions and world views with playful ease and little concern for fundamentalist strictures, as when the portraits of Marx and God are juxtaposed and Marji realizes "how much Marx and God looked like each other," ${ }^{\prime 39}$ or when the monkey king completes the classical Chinese Journey to the West in a portrayal of the Virgin Mary and a happy baby Jesus reaching for the monkey king's hand. ${ }^{40}$ Moving on from these first superficial indications for taking the visual space Satrapi and Yang unfold as a cosmopolitan space, I want to take a closer look at the way in which the tensions and contradictions between the universal and the particular are drawn out in both graphic novels.

Comic theorist Scott McCloud has ascribed a universal dimension to cartoon imagery which is now often-cited in the critical discussion on graphic novels dealing with issues of intercultural translation. By "cartooning"/41 culturally bound stories, they are raised to a level of abstraction which removes them from their original context and makes the story available beyond it: "When you look at a photo or realistic drawing of a face, you see it as the face of another. But when you enter the world of the cartoon, you see yourself"42. In a way, the cartoon images seem to be able to go where language can't. Leigh Gilmore connects this potential of the image even with representations of trauma. While trauma studies have shown that "language fails to adequately convey trauma," "representations of trauma abound," ${ }^{143}$ particularly in newly emerging artistic forms such as "visual autobiography and memoir." ${ }^{144}$ Maybe it is not coincidental that stories about migration and cultural uprooting, largely shaped by experiences of the crossing of linguistic barriers and experiences of alienation, strangeness and isolation which seem to escape a shared, common language, turn to the comics medium to narrate these stories.

Many reviews have lauded Persepolis for presenting a universally accessible story because it places a child at the center of the narrative..$^{45}$ But to which extent is it true that the child's perspective is a universal perspective? Do we see a universal picture when we look at the world of growing up through Marji's and Jin's eyes? The idea of the universality of childhood or the child's perspective derives from the perception of the child as yet to be

38 Cf. Chute, "The Texture," 11.

39 Satrapi, Persepolis, 13.

40 Yang, American Born Chinese, 215.

41 Scott McCloud, Understanding Comics: The Invisible Art (New York: Harpercollins, 1993).

42 McCloud, Understanding Comics, 36.

43 Leigh Gilmore, "Witnessing Persepolis: Comics, Trauma, and Childhood Testimony," in ed. Michael A. Chaney, Graphic Subjects: Critical Essays on Autobiography and Graphic Novels, (Madison, WI: University of Wisconsin Press, 2011), 158.

44 Gilmore, "Witnessing Persepolis," 158.

45 Cf. Chute, "The Texture," 4; Nima Naghibi and Andrew O'Malley, "Estranging the Familiar: 'East' and 'West' in Satrapi's Persepolis," ESC 31.2-3 (2005): 226. 
cultured, as yet having to acquire those traits which would then differentiate it as belonging to a particular community. But it is exactly this understanding of childhood which both Satrapi and Yang complicate. Furthermore, they equally undermine and subvert the corresponding idea of the immigrant. The immigrant does not leave one self-contained cultural realm in order to then enter a new, equally closed, cultural world to which she has yet to become accustomed just as the child has to learn the ways of the adult world. Rather, in both books, despite the universal appeal of "cartooning" discussed above, particularity is introduced and visualized in a way that creates precarious tensions with the universal aspirations and appears to counteract the appeal to an underlying (or superficially) shared sameness. However, I think it would be a misreading of both stories if one were to conclude, as Naghibi/O'Malley do with regard to Persepolis, that the child as the autobiographical subject, as well as the juvenile medium and the simplistic drawing style "effectively 'camouflage' the complex politics of identity and nation [...] in the guise of simplicity and universal accessibility. ${ }^{146}$ On the contrary, I believe that the medium, the style, and the child as the narrative's subject should be taken more seriously, and can be taken more seriously from a critical cosmopolitan perspective. Because then it can be shown that Yang and Satrapi not only complicate simplistic universalisms, but equally complicate the narrow rigidity of certain forms of particularism. This is a claim which requires taking the authors' formal choices clearly into account in the interpretation of their way of visualizing cross-cultural experiences, rather than reducing the comic form and the child as autobiographic subject to a mere marketing asset. From such an approach a different picture can emerge of where Satrapi and Yang stand with regard to universalism and particularism. In the picture I want to offer here, they are both as wary and critical of "the limitations and dangers involved in a too-protectionist approach to assertions of identity or primary affiliation ${ }^{1 / 47}$ as they are of abstract universalism.

Interestingly, Michael A. Chaney describes the effects of cartooning as almost in opposition to the universalizing quality that McCloud, and the others discussed above, pointed to, when he emphasizes that autobiographic comics as "realistic fictions of the self prod us to reconsider [not only] what is at stake in telling our life stories in pictures, [but also] how it is that we have come to visualize identity in particular ways and according to particular sociohistorical contexts." ${ }^{148}$ This appears to me to be pointing to the way in which the comics form also lends itself to depict particular identities rather than just invite universal identification. While the stylization of the autobiographic ' $\mathrm{l}$ ' as a cartoon necessarily leads to a departure from realistic depictions of the autobiographic subjects, in this way universalizing it, the cartoon image is at the same time very effective in iconographically picking out the visual stereotypes we have come to associate with specific socio-cultural identities, in this way particularizing the subjects and their contexts. The character of Chin-Kee in Ame-

46 Naghibi/O'Malley, "Estranging the Familiar," 234.

47 Anderson, "Cosmopolitanism, Universalism," 266.

48 Chaney, Graphic Subjects, 7. 
rican Born Chinese embodies a glaring example of such stereotypical representation in the comics form: the pale yellow skin, his slanted eyes and the oversized front teeth protruding over his lower lip ${ }^{49}$ quote all the features which together constitute the visual caricature of the Asian 'other' in US society. But even if the sit-com character Chin-Kee visually embodies the negatively connoted Asian stereotype in a particularly overdrawn and radically exaggerated way, also the children in the more realistically presented coming-of-age storyline of Jin Wang are drawn in a clearly racializing manner. The pale skin color, black hair, and slightly slanted eyes of the isolated Asian children explicitly contrast with the pink skin color and lighter hair of their fellow students, ${ }^{50}$ and the visual stereotype is quoted again when Danny catches some of his classmates ridiculing Chinese identity by making slit-eyes. ${ }^{51}$ In Persepolis the iconography of the veil is interesting to look at in order to illustrate this particularizing potential of the comics form when it cites visual socio-cultural stereotypes. The distinction between "the two images of Eastern Marji and Western Marji"52 is visualized first and foremost by the protagonist's wearing of the veil or the omission of the veil. Of course, neither Persepolis nor American Born Chinese content themselves with the depiction of the stereotypes. However, I think it is important to keep in mind this potential of comics for an uncomfortably easy and straightforward depiction of difference through the portrayal or quotation of visual stereotypes, alongside its potential for universalizing abstraction discussed above, as well as its potential to undermine, transgress and transform these stereotypes on the page.

\section{Transformation and (Un-)veiling: Stories of Self-appropriation and Arrogation of Voice}

As the social philosopher Rahel Jaeggi ${ }^{53}$ has argued, both an understanding of the self as a (hidden) thinglike, given object which we passively experience and can discover as well as an understanding of the self as something that is constructed at will or could be produced instrumentally represent distorted, alienating forms of self-relation. Similarly, the Wittgenstein scholar David Finkelstein ${ }^{54}$ has rejected what he calls "detectivist" and "constitutivist" conceptions of the self. It is important for the following discussion of the development of the self-relations in graphic novels that neither Finkelstein's expressivism nor Jaeggi's concept of self-appropriation presuppose a pre-existent 'true' self, just as in Stanley Cavell's Emersonian account of the self, there is no 'real me' apart from its continuous founding in language between inheritance and transgression. When Cavell reads Emerson's "self-reli-

49 Cf. Yang, American Born Chinese, 43.

50 Cf. Yang, American Born Chinese, 36.

51 Yang, American Born Chinese, 121.

52 Naghibi/O'Malley, “Estranging the Familiar," 231.

53 Rahel Jaeggi, Entfremdung - Zur Aktualität eines sozialphilosophischen Problems (Frankfurt a. M.: Campus Verlag, 2005).

54 David Finkelstein, Expression and the Inner (Cambridge, MA: Harvard University Press, 2008). 
ance" as an aversion to conformity, this implies aversion to our own individual old beliefs and habits, not just to averse ourselves to conforming to the norms of others. Self-reliance means acknowledging the fact that "the soul becomes" on an individual and societal level..$^{55}$ For Jaeggi, the idea of self-appropriation is based on a non-essentialist definition of forms of self-relation which are not alienating. It suggests a structural formal analysis of whether further experiences and new forms of appropriation are made possible or inhibited by it, rather than an ultimate core identity which can be detected or should be constructed. One's own wishes, intentions, emotions, and perceptions cannot be assumed unproblematically given as one's own, but they nevertheless require to be considered as worthy of critical exploration, appropriation and articulation. In the following I will now discuss with the help of some examples from both graphic novels how the main characters' self- and world-relations are transformed in a process of continual appropriation of the cultural environments they move in. I will look at the theme of transformation pervading American Born Chinese and the theme of (un-)veiling in Persepolis respectively. Against purist ideas of cultural identity just as much as against too facile abstract universalisms, the symbols of the transformer toy and the veil retain a doubleness in evoking sameness as well as difference and provoking our thinking at the limits of both.

The topic of transformation is broached rather innocuously in the first chapter of American Born Chinese when the monkey king is shown to be able to change his form in typical comic superhero manner. ${ }^{56}$ However, the "thick smell of monkey fur" ${ }^{157}$ follows him and prevents him from being accepted as a deity. The rejection of the monkey king despite his deity-like powers of transgressing his given physical form is paralleled shortly after in the storyline of Jin. Following his mother to a herbalist, Jin sitting in the waiting room receives a warning from the herbalist's wife. Jin is fascinated with his transformer toy and tells the herbalist's wife that he would love to be a transformer himself once he grows up to which she responds, "It is easy to become anything you wish ... as long as you are willing to forfeit your soul." 58 The endless possibilities of constructing one's own image in the cartoon form as opposed to the limits of transforming one's physical appearance in real life are discussed further when Jin admits to her that the transformer toy in the cartoon becomes a truck with a trailer, but the real toy only becomes a truck and the trailer comes in a separate piece. $^{59}$ The motif of the unlimited possibilities of transforming one's image on the comic page as opposed to the limits and ludicrous consequences of such attempts at self-construction in real life is repeated throughout the book at various stages and in various forms.

When the storylines of Jin Wang and Danny are first introduced, they are perceived as parallel to each other, but not connected. The reader has no way of "seeing" that Jin and

55 Cf. Claudia Schumann, "The self as onwardness: reading Emerson's self-reliance and experience," Foro de Educación 11.15 (2013), doi: 10.14516/fde.2013.011.015.001.

56 Cf. Yang, American Born Chinese, 10-11 and 58.

57 Yang, American Born Chinese, 20.

58 Yang, American Born Chinese, 29.

59 Cf. Yang, American Born Chinese, 28. 
Danny are one and the same character because their visual portrayal is not linked until the last chapter of the book. ${ }^{60}$ The protagonist's image shifts from the racialized portrayal of the young Jin to the split depiction of his identity in the form of the white, attractive high school hero Danny and the caricature of Chin-Kee in the sit-com storyline. The conflict between Chin-Kee and Danny, between the racist stereotypes of Chinese identity and Jin's inner picture of himself, increases continuously throughout the story. His imagined identity as a blond American teenager smoothly fitting into the mainstream is visually constructed on the comic page in convincing realistic detail. Finally the conflict escalates in a physical fight between Jin's two self-images to the point where Danny cuts Chin-Kee's head of in order to eradicate this picture of himself.

Once Chin-Kee has been beheaded he reveals his "true form"61 and shows himself as the monkey king. Consequently, Danny's face also transforms back into Jin Wang's. The exaggerated negative stereotype of Chineseness transforms into the monkey king, "the legendary trickster figure [...] a source of cultural strength, a symbol of subversion and resistance,"62 in this way allowing for Jin to come to terms with and regain pride in his Chinese heritage because he finds a way of self-appropriation in the trickster figure that goes beyond the dichotomy of either constructing his identity in conformity with American mainstream ideals or accepting his Chineseness and conforming to the limited stereotypical identity others have assigned to him. The 'transformation' of one's physical appearance in the sense of constructing your looks to conform to the mainstream is doomed to failure and requires the willingness to "forfeit your soul." But in a positive sense, 'transformation' entails the possibilities of self-appropriation by aversion to the conformity of the mainstream as well as of the minority stereotype. The intertextual reference on the very last page of the book adequately symbolizes this double aversion. In this last image jin re-enacts a YouTube video meme by two Asian teenagers lip-synching to a song by the Backstreet Boys. The original video had gained wide popularity on the internet as a site for racist ridicule. The transformation on the last page stands as a reminder of the power of the trickster figure, of the possibilities of self-appropriation also through the subversive powers of sarcasm and mockery, of the possibility of aversion to the stereotype and transforming it into something you can own.

In Persepolis we find a similar exploration of the possibilities and limits of self-acceptance, self-construction, and self-appropriation, but its violent and brutally traumatic themes push this exploration to further edges. In contrast to the Disney colors and the youthful style of American Born Chinese, we find a "radical disjuncture between the oftengorgeous minimalism of Satrapi's drawings and the infinitely complicated traumatic events they depict: harassment, torture, execution, bombings, mass murder." ${ }^{163}$ Furthermore, the

60 Cf. Yang, American Born Chinese, 214.

61 Yang, American Born Chinese, 213.

62 Fu quoted in Davis, "American Born Chinese," 280.

63 Chute, "The Texture," 12. 
visualization of particular identity in Persepolis not only relates to the problematic of physical appearance as a site of racism, but further extends to questions of class, gender, and the symbolization of culturally specific ideas of freedom which are played out in an exemplary manner within Persepolis' multi-layered engagement with the iconography of the veil. The story of the veil opens the book as the first chapter of Persepolis I. Maybe surprising for some western readers, the veil is introduced as something relatively new to Marji's world. We see her somewhat grumpily wearing a veil sitting in a school bench, and then tearing it off and appropriating it for silly play in the schoolyard. Later the veil is shown in relation to the beginning of the separation of boys and girls in schools, and women in veil demonstrate for "the veil" while unveiled women demonstrate for "freedom" in the streets of Teheran ${ }^{64}$ However, the veil never reduces to the symbol of the religious backlash of the "cultural revolution" in Satrapi's story. The child character of Marji herself is drawn as split between her spiritual, veiled half against a background of Persian ornaments, and her unveiled, avant-garde half against the background of multiple technical instruments. ${ }^{65}$ The split, cutting clearly through the middle of the figure, suggests that the two traditions of the unveiled secular modern and the newly re-introduced, veiled religious tradition constitute a disjuncture within the character's identity and stand in unmediated contrast to each other. Later on in the story Satrapi also shows how the veil is adapted in order to visually demonstrate political affiliation. ${ }^{66}$ She not only juxtaposes women's "modern" vs. "fundamentalist" styles of appropriating the veil, but complements this image with a contrastive look at the "modern" vs. the "progressive" man. ${ }^{67}$ Under the growing pressure of state legislation and violence, the opposition "veiled - unveiled" no longer coincides with the opposition of "religious - modern," but has shifted to a point where the contrast is now expressed within oppositional modes of wearing the veil. In this way Satrapi's images of Iranian women introduce first nuances to the stereotypical association of the veil with Islamist fundamentalism in the West, and she further complicates this notion in drawing out that similar distinctions apply in clothing for men. Satrapi sensitizes the readers' seeing to how, with the increasing brutality of political oppression by the state, the possibilities for visual aversion to the dictates of the ruling norms become smaller, but they remain no less visible.

The expressive distinctions between modernist and religious men and women, while contaminated by state violence, still remain stable, but gain a further twist with the transition from Persepolis I to Persepolis II and Marji's departure for Austria. The overbearing black of the silhouettes in the tragic good-bye scene at Teheran airport is picked up again on the first page of Persepolis II where Marjane finds herself again surrounded by black veils; veils of the catholic Austrian nuns in the convent. The imagery is only slightly altered

64 Satrapi, Persepolis, 5.

65 Satrapi, Persepolis, 6.

66 Cf. Satrapi, Persepolis, 75.

67 Satrapi, Persepolis, 75. 
through the contrastive white of the crosses hanging from their necks. Even though veils then remain absent for the remainder of Marjane's years in Austria, they do not disappear completely, but are inverted - with the topic of unveiling gaining stronger presence. During the time in Austria, we are shown how Marjane first sees naked bodies ${ }^{68}$ and is affected by the bodily changes of puberty, to which she reacts by constructing a new identity for this new body, adorning it with the accessories that would define her as part of her newlyfound group of punk friends. ${ }^{69}$ But when her body becomes the site of racism, there is no escape from these attacks. Her face unveils her as what she is in the eyes of many Austrians - an Iranian immigrant, an "Ausländer" not worthy of being their brother's or son's girlfriend, or even of sitting next to them on the bus. ${ }^{70}$ Faced with the ridicule of some Austrian girls for her attempt at disguising her Iranian roots, Marjane realizes that she is not free to invent herself anew, but that when attacked as an Iranian, she has to defend herself as an Iranian. Screaming, "I am Iranian and proud of it"71 in all capital letters on the page, Marjane appropriates something which she could neither abandon at will nor reconstruct as something other and more fitting with the norm.

The logic of multiple aversions to conformity underpins the journey of self-appropriation in both American Born Chinese and Persepolis. Laying claim to one's particular history and cultural identity beyond merely accepting rigid pre-defined givens and continuously negotiating the limits and desirability of constructing oneself in accordance to norms set by others, the characters' struggle for founding a self-reliant voice that can rightfully count as their own is portrayed as a struggle with many pitfalls, a struggle against many odds with the constant potential for failure, in which we ultimately cannot definitely know if we succeeded or failed and which is nevertheless deemed worthy fighting.

There is a special connection between the critical cosmopolitics I have in mind and auto(bio)graphy because putting forth one's issues for the world to hear and consider requires a certain arrogance, or as Stanley Cavell says an "arrogation of voice".72 He describes Thoreau's and Emerson's "philosophy of immigrancy, of the human as stranger" as "beginning no doubt with the strangeness of oneself".73 It is this investigation into the strangeness of oneself that further aligns the two autobiographical comics with the "current manifestations of cosmopolitanism" which according to Anderson "all tend to be highly self-reflexive about the problem of elitism".74 Satrapi and Yang are both highly self-reflexive in regard to the characters' social position. Despite being positioned in the margins of their respective immediate communities, with Marji's parents being part of the political opposition

68 Satrapi, Persepolis, 189.

69 Satrapi, Persepolis,191f.

70 Satrapi, Persepolis, 197f., 222.

71 Satrapi, Persepolis, 199.

72 Cf. chapter 1 in Stanley Cavell, A Pitch of Philosophy. Autobiographical Exercises (Cambridge, MA: Harvard University Press, 1994).

73 Cavell, A Pitch, xv.

74 Anderson, “Cosmopolitanism, Universalism," 285. 
and later due to her immigrant status, and Jin because of racial prejudices, they both also acknowledge the impact of their relatively privileged backgrounds, with their families placing high importance on a good education, encouraging setting ambitious goals for oneself, as well as fostering an ethical uprightness. In this way they both openly discuss the privileged conditions under which they can dare to found their own voice.

At the same time, however, there is also a poverty and humility in such an arrogation of voice in this cosmopolitics of the ' $I$ '. For what I am putting forth is what I find to be important, and what I can stand for. I am not claiming to speak for everybody. I am not claiming that my life experiences and the political issues of importance to me should necessarily and universally be the same issues for everybody else. But, in a cosmopolitan stance, I am claiming not merely to speak from a particular category of identity (as a woman, as a Muslim, as a German, etc.). Cosmopolitics as the arrogation of independent judgment, as the arrogation of resistance against being determined by reified particular conditions as well as against being consumed by universals constructed by others, becomes the insistence on continuing the strive for founding a self-reliant voice against all odds, and believing that this voice is worth being heard by the world. At the same time such a cosmopolitics naturally implies an openness for being impacted and transformed by potentially any other voice in the world - not just respective local, particular, or self-proclaimed universal authorities. Satrapi and Yang both interestingly show another side to cosmopolitanism than the joyful and pleasurable. Both stories involve traumatic experiences and make explicit the enormous risks involved in looking back and in founding a voice. In this way the ethical dimension of cosmopolitanism is put to the forefront and we arrive at a more complex, nuanced and intense picture of what is required for the founding of a self-reliant voice.

Cavell states that some might perceive his interpretations of the topic of strangeness in Thoreau and Emerson "as a clinical issue, with more bearing on myself than on those I claim to perceive", 75 and he wishes to be "excused for seeing it also as a critical issue, enabling genuine perceptions that might otherwise go unwon"7 ${ }^{6}$ This two-way path is available to a reading of the texts in question, too. I hope to have shown that the stories give expression to more than to the effects certain devastating and violent experiences, as in the case of Persepolis, and certain quotidian experiences of prejudice towards perceived strangers, as in American Born Chinese, have on the individual psyches of the author-narrator. They are also not just extended clinical analyses in the sense of claiming that this effect would take a hold on any human being, not just a human being with a similar psychological condition as the author-narrators. By putting too much emphasis on the psychological, many interpreters run the danger of placing the stories too close to the clinical, thus overlooking the critical. It is important for understanding the stories, in my view, to look very closely at how they exceed the clinical and voice a critical perspective, how they articulate a transformative vision of society through critical self-investigation. This is where their political dimen-

75 Cavell, A Pitch, xv.

76 Cavell, A Pitch, xv. 
sion opens up. Through their portrayal of the visual aversions on the page both Yang and Satrapi show that the authorial self is not there as one to be "detected", and they also show the limits and pitfalls of "constructing" a self for the purpose of fitting conventional expectations, rather the authorial self co-exists in a multiplicity of forms simultaneously on the page and requires work in order to be appropriated again and again in the everyday. In a democracy that is to amount to more than mass conformism such social critique through "ordinary" self-appropriations is integral to any democratic politics. 